\title{
Työelämän pelit muutoksessa
}

Anu Järvensivu (2010). Tapaus työelämä - ja voiko sitä muuttaa? Tampereen Yliopistopaino Oy. 294 S.

Ennen sitä kutsuttiin vaivaksi. Vaiva on vähintäänkin jokin oire. Sittemmin 1600-luvulta lähtien sitä on nimitetty toisin. Se ei ole kuitenkaan sairaus tai syndrooma - se on työ. Anu Järvensivun kirja on nimeltään ”Tapaus työelämä - ja voiko sitä muuttaa?". Tapaustutkimusta on puolestaan käytetty paljon lääketieteessä ja sairastavien tyypittelyssä. Voitaisiin hyvinkin päätyä tulkintaan, että työelämä oireilee tai siinä on jotakin vikaa; miksipä otsikko muutoin sisältäisi kysymyksen muutoksesta.

Järvensivu on tarkastellut kirjassaan työelämää tavoitteena saada jokin "tolkku" siihen, mitä kaikkea se on tänään, millaisin pääomin siellä pelataan ja miltä se konkreettisella, kokemuksellisella tasolla näyttää ja millaiseksi se muuttuu.

Tarkasteluaikaväliksi on valittu 1980-2010 ja oletuksena on, että tällä aikavälillä työssä on tapahtunut oleellisia muutoksia ja siellä toimivien on tästä syystä selviydyttävä uusilla strategioilla. Eräänä väitteenä muiden joukossa onkin, että "elämme parhaillaan yhteiskunnan tasolla jonkintasoista työelämän pelin käännekohtaa” (s. 29). Sosiologisesti orientoituvassa tekstissä käytetään tolkun tavoittamiseksi hyvin paljon yleiskäsitettä työ. Huolimatta ter- mien (tolkku ja työ) todella laajaalaisista merkityksistä kussakin kirjoituskontekstissaan niillä tavoitetaan hyvin käsitteisiin liittyvä tarkoitus.

\section{TYÖELÄMÄ PELIKENTTÄNÄ}

Menetelmällisesti kirjan erilaatuiset materiaalit nähdään (tasaarvoisesti) empiirisinä aineistoina ja ne on viety analyysimuodossa esitykseen ja paikoilleen työelämän kentälle, jossa tapahtumia ja ilmiöitä kuvataan pelimetaforien kautta. Työelämä kuvataan pelikenttänä työelämätutkijoille tutun Michael Burawoyn ja sosiologiastaan yleisemmin tunnetun Pierre Bourdieun mukaisesti. Kentällä pelaaminen edellyttää pelaajia, sääntöjä, pääomia. Pelaajakohortit muuttuvat, sääntömuutoksiin on ristiriitojen vuoksi paljon painetta ja uusia pääomia on kehitettävä selviytymis- ja pelistrategioiksi niin, että pelaajat suostuisivat edelleen pelaamaan yhteistä peliä. Peli ei voi muuttua sujuvasti ja ilman törmäyksiä toiseksi silloin, kun kenttä muuttuu syystä tai toisesta eikä sääntöjä ole uusittu. Tällöin keskeinen peliin kiinnittymistä luova tekijä, luottamus, on vaarassa kadota. Tuomareita ei tässä Järvensivun rakentamassa pelissä paljon näy kuten ei myöskään yleisöä - kaikkien työssäolijoiden tai kentän liepeillä olevien, sinne tulijoiden ja poistujien oletetaan olevan pelissä jotenkin mukana tai ymmärtävän tämän toiminnan.

Kirjan sivuille työelämän tutkimus- ja kehittämistyötä paljon tehnyt Järvensivu kuljettaa runsaasti materiaalia sekä muista, lähinnä suomalaisista työelämän tutkimuksen teksteistä että omien empiiristen tutkimustensa materiaaleista. Omat materiaalit sisältävät paljon erilaisten alojen työntekijöiden ja työnantajien haastatteluaineistoista valittuja tekstejä. Molemmista aineistoista kirjassa tavoitetaan kokemuksellisuus ja arjen käsitysten fenomeeninen taso. Aineistot ovat runsaita ja kirjassa vältetään jonkin yhden ja valitun sisällöllisen hypoteesin (kurjistuminen, polarisoituminen, ym.) tai kehityskulkuun vaikuttavan tekijän (arvonlisäys, teknologia, työn organisoimisen strategiat, työmarkkinat, ym.) todistamiselta. Runsaat aineistot todistavat, että jokin yksittäinen tekijä ei liikuta peliä, vaan yhdessä seikassa tapahtuvat muutokset heijastuvat moniin tekijöihin, jotka puolestaan liikuttavat pelin kokonaisuutta "dynaamisen systeemisen logiikan" mukaisesti (s. 24).

Kirjan otsikon lupaus siitä, että lukija löytäisi muuttamisen välineet, ei toteudu ja edetessään itse tekstikin alkaa puhua muuttamisen sijaan muuttumisesta ja muutoksista (koko alaotsikko "tapaus työelämä ja sen muuttuminen", 
s.265 alkaen). Toki osallistumista ja aktiivista pelaamista suositellaan ratkaisuina sen myötä, että todetaan työelämän toimijoiden pyörittävän peliä, joka muutoin ei toteutuisi ollenkaan. Aktiivisia pelistrategioita pidetään ainoina muuttavina ja vaikuttavina tekijöinä (mahdollisesti jopa unohtaen sen, että passiiviset ja puolustusstrategiat saattavat olla dominoivia ja peliä yhtä lailla rakentavia).

\section{OPPIMINEN JA KOULUTUS PÄRJÄÄMISPÄÄOMAA}

Erityisesti aikuiskoulutukselle Järvensivun kirja tarjoaa sekä eksplisiittisesti että rivien välistä tärkeää luettavaa. Oppiminen ja koulutus nimittäin ovat nousseet tärkeiksi työelämän muutostekijöiksi ja strategisiksi, aktiivisiksi pärjäämispääomiksi hyvin eri tavoin, jotka jätän tässä tarkemmin kirjan lukijan löydettäviksi. Oppimiselle on paljon tilausta ja siltä myös paljon odotetaan. Ongelmana vain on toistaiseksi se, että työelämän edustajat eivät näe juuri formaalilla koulutuksella olevan tuossa muutospelissä roolia ja oikea oppiminen tapahtuu vasta ja aina työpaikoilla.

Järvensivun empiirisen aineiston tekstien pohjalta kuilu oppilaitosten ja työelämän välillä on vielä valtava. Sivuhuomautuksena voidaan todeta, että se on samankaltainen myös työnsosiologisissa ja työelämätutkimuksen teksteissä, joissa (ammatillinen) koulutus ja oppiminen yleensä jäävät vaille minkäänlaista kiinnostusta tai positiota. Jo lähtökohdiltaan koulutusaffirmatiivinen kasvatus- tieteellinen tutkimus puolestaan vahvasti vetoaa "työelämän vaatimuksiin" mitä erilaisimmissa asioissa.

On tietenkin syytä kokoavasti kysyä, millaista peliä Järvensivu itse on kirjassa pelannut? Vahvoja pelintekijöitä ovat muut suomalaiset tutkijat ja tekstit, joita luontevasti ja ytimekkäästi käytetään oleellisia siirtoja tehtäessä. Haastattelujen muodossa työelämän vastapelaajat, työnantajat ja työntekijät, tuovat esille hyvää materiaalia pelin avautumiseksi ja pelistrategioiden ymmärtämiseksi. Tärkeänä ajallisuutta tuovana referenssinä ja myös teoreettisen valmentajan roolia antaen Järvensivu palaa toistuvasti hakemaan tukea ja kiittämään Simo Ahon "jo 80-luvulla" lisensiaatintyössä tekemiä analyyseja ja ennusteita palkkatyön kehityspiirteistä ja normalisaatiosta.

Useimpien muiden kirjoittajien tekstejä kommentoidaan ja käytetään tekstipelin etenemiseksi sujuvalla ja teemoja rikastavalla tavalla. Pelin taustalla on toki paljon tamperelaisen työelämätutkimuksen teoriaperinnettä ja bourdieulaisen kentän, pelistrategioiden ja pääomien käsitteiden käyttö tuo siihen lisäarvoa ja -väriä. Vahvana pelivälineenä ja käytettynä metodina metaforat toimivat hyvin ja tuottavat meneillään olevaan työelämäpeliin helposti tavoitettavaa ymmärrystä.

\section{LATTIATASON ILMIÖT PELIKENTÄLLE}

Jää myöhemmin arvioitavaksi se, onko tämä ratkaisu kuitenkin metatason ansa. Nyt lukija ei aina ole selvillä mitä peliä pelataan ja millaisilla säännöillä itse peli muodostuu - ja onko se edes peliä, jossa ei olisi sääntöjä? Jääkö asia kuitenkin helpon ilmaisun kautta vieraaksi - moni lähtee aamulla töihin eikä pelaamaan peliä! Lievä vieraannuttaminen on toki myös hyvä draamallinen väline itse asian korstasmiseksi. Jokainen voi tunnistaa kuitenkin töihin mennessään sen, että niin oma työ kuin nyt bourdieulaisittain kuvattu suomalainen työ-pelikin on täynnä ristiriitoja ja dynamiikkaa, jopa epätasa-arvoa.

Vaikka pelistä puuttuvat muuttavien tekijöiden analyysi ja esimerkiksi tamperelaiselle perinteelle kovinkin tärkeä luokka- ja (bourdieulainen) kerrostumanäkökulma - pelin "tähdet" kylläkin saavat pienen huomionsa ja pelaajat on perinteisesti jaettu luokkaperusteisesti - on tapaus työelämä muutoksessaan ainakin "metabolinen oireyhtymä" ja monien muutostekijöiden vaivaama. Ja vaikka pysytäänkin pelin pinnalla ja kuvailevalla tasolla, on kirjan parasta antia juuri se, että työelämän lattiatason ilmiöt nostetaan pelikokonaisuuden kontekstiin. Ilman tilastoaineistoakin lukija tavoittaa elämismaailman tasolla "normaaliksi" useita työelämän ilmiöitä, joiden on sanottu vasta tulevan - ne ovat jo täällä.

Useasta syystä kirja on mukavaa ja tarpeellista luettavaa.

Heikki Pasanen

yliopettaja, Haaga-Helia

Ammattikorkeakoulu, Ammatillinen opettajakorkeakoulu 